\title{
A New Polarographic Wave due to the Anodic Formation of Zinc Tetrathiocyanatomercurate(II)
}

\author{
Tomihito Kambara, Takuji Saheri* and Shigeyuki Tanaka** \\ Department of Ghemistry, Faculty of Science, Hokkaido University, Sapporo, Japan
}

(Received Feb. 23, 1970, revised Sep. 12, 1970)

\section{Summary}

\begin{abstract}
Addition of zinc ion in a concentration higher than $0.5 \mathrm{mM}$ to the supporting electrolyte of $1 M$ potassium thiocyanate results in the appearance of an anodic wave due to the formation of the ternary complex of zinc tetrathiocyanatomercurate(II). This wave is very faint in DG step, but very prominent in AG peak. Evidences for the adsorption process involved in the anodic depolarization are given.
\end{abstract}

Formation of the slightly soluble precipitate of tetrathiocyanatomercurate with bivalent metal ion is especially useful for the spot test of zinc $^{1,2)}$ and the solubility product data for zinc and cobalt are compiled. ${ }^{3)}$ As well known, some anion forming slightly soluble precipitate or stable complex with mercury ion shows anodic wave, the polarographic properties of which have been clarified by Revends) and Kolthoff with Miller. ${ }^{5}$ Especially the stepwise formation of mercury(II)-thiocyanate complex is investigated by Nyman and Alberts. ${ }^{6)}$ It is now expected that in the presence of bivalent cation thiocyanate ion would depolarize the mercury anode resulting in the precipitation of tetrathiocyanatomercurate(II) and consequently an anodic wave of new type would appear. In the present paper an example of anodic wave due to the formation of a three-component complex is reported.

\section{Experimental}

Apparatus The DG and AG polarograms are recorded by means of a Shimadzu polarograph, type RP-2, together with an AG attachment, type BF-1, the circuitry of which is proposed by Ishibashi et al. ${ }^{7)}$ The capillary characteristics were: $m=1.484$ $\mathrm{mg} \mathrm{sec}-1$ in pure water at $18^{\circ} \mathrm{C}, t=3.80 \mathrm{sec}$ in the electrolysis solution at open circuit at $h=58 \mathrm{~cm}$.

The HF polarograph used was a Yanagimoto product, type PF-500, in which a

*Present address : Kyorin Pharmaceutical Co., Ltd., Nogi Factory, Nogi-cho, Shimotoga-gun, Tochigi Prefecture.

**Present address : Hitachi Maxell, Ltd., Ushitora, Ibaraki-shi, Osaka Prefecture. 
$200-\mathrm{Hz}$ square-wave voltage is modulated by a $\mathrm{HF}$ potential of $455 \mathrm{kHz}$. In this case the capillary characteristics were: $m=0.800 \mathrm{mg} \mathrm{sec}{ }^{-1}, t=3.59 \mathrm{sec}$ at $h=90 \mathrm{~cm}$.

Reagents The reagents employed were all of analytical grade. Resin-deionized water was used.

\section{Results and Discussion}

Fig. 1 shows the DC polarograms of the aqueous $1 M$ potassium thiocyanate solutions containing zinc ion, and Fig. 2 reproduces the corresponding AC polarograms. In DG polarograms one can find a so faint step that one would regard it as due to a certain mechanical shock or to the resistance caused by a bad electrical connection. This step is seen, however, only in the presence of zinc ion and the corresponding AC peak is extraordinarily prominent. It may be safe to say that by the aid of zinc ion thiocyanate ion can depolarize mercury anode more easily, i.e., at the more negative potential than in the absence of zinc ion. Thus, one finds now a new anodic wave when zinc ion and thiocyanate ion are present at the same time.

Fig. 3 shows the dependence of the AG peak height on the zinc ion concentration. Below the critical zinc concentration of $0.5 \mathrm{mM}$, the new wave does not appear. The AC peak height increases linearly with zinc ion concentration until the second critical concentration of $2.1 \mathrm{~m} M$ is reached. When the zinc concentration increases over 2.1 $\mathrm{m} M$, the $\mathrm{AC}$ peak height now increases more slowly but linearly.

The fact that the new wave due to the formation of the ternary complex is vanishingly small in DG step, but most remarkable in AG peak, suggests that in the anodic

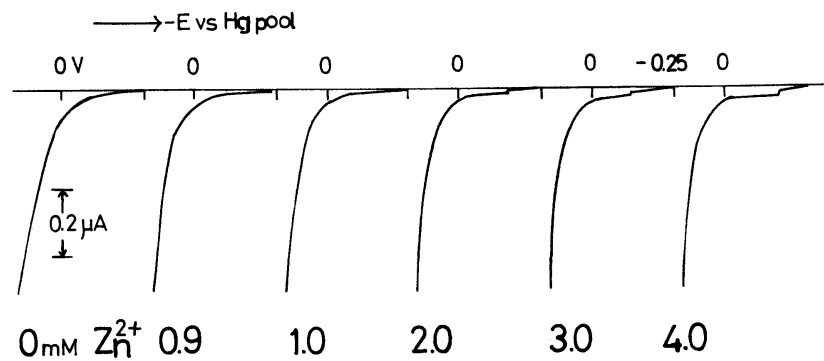

Fig. 1. DG polarogram of $1 M \mathrm{KSGN}$ containing zinc ion in various concentrations. Oxygen purged. $20 \pm 0.5^{\circ} \mathrm{C}$. Damping $1 \mu \mathrm{F}$.

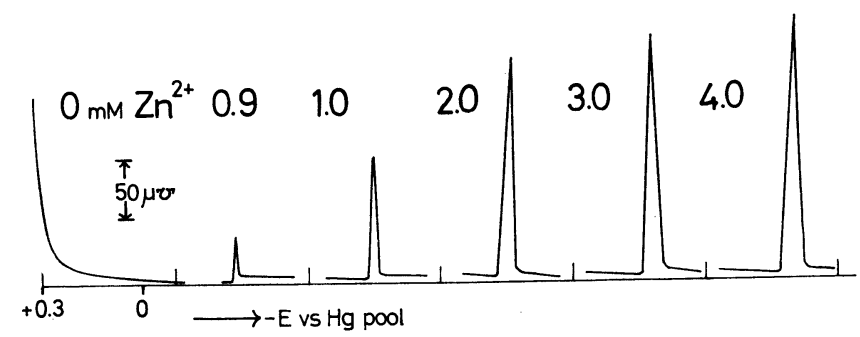

Fig. 2. AG polarogram corresponding to Fig. 1. Damping $3 \mu \mathrm{F}$. Sensitivity adjust $90 / 100$. AG voltage amplitude $=20 \mathrm{mV}$. Compensation capacitance $0.3 \mu \mathrm{F}$. 


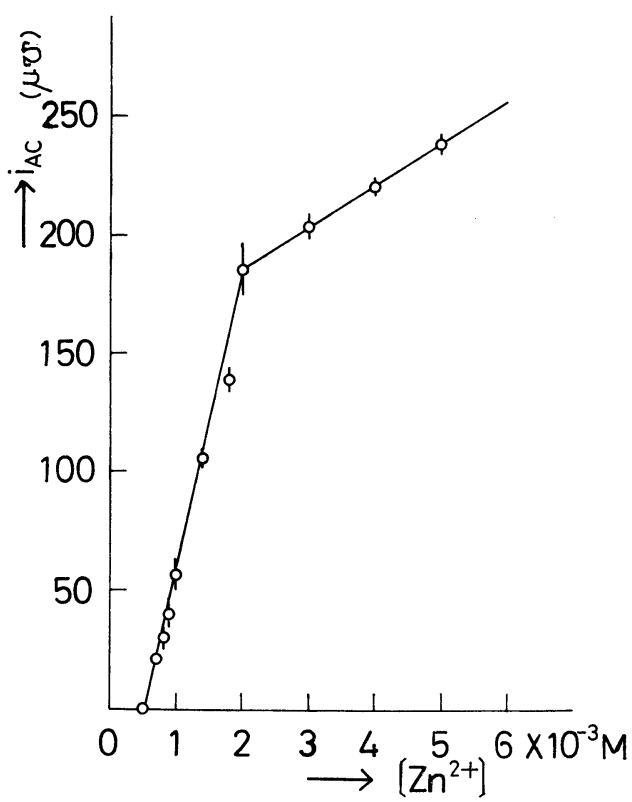

Fig. 3. Variation of AG peak height with zinc ion concentration. Solution and experimental conditions are the same as in Fig. 2. Vertical line indicates $99 \%$ confidence limits.

process is involved an adsorption process. Measurement of the electrocapillary curve shows also a clear cut-in at the peak potential. This is the AC peak defined by Breyer et $a{ }^{8}{ }^{8}$ as the transition wave and many substances showing such a character of redox plus adsorption are found in the monograph. ${ }^{9)}$ In Fig. 4 is seen that the temperature coefficient of the new $\mathrm{AC}$ peak height becomes negative in the temperature range higher than $15^{\circ} \mathrm{C}$. This tendency suggests most strongly the transition wave character.

It is then expected that the new wave would show a very high sensitivity in highfrequency polarography. The result is shown in Figs. 5 and 6.

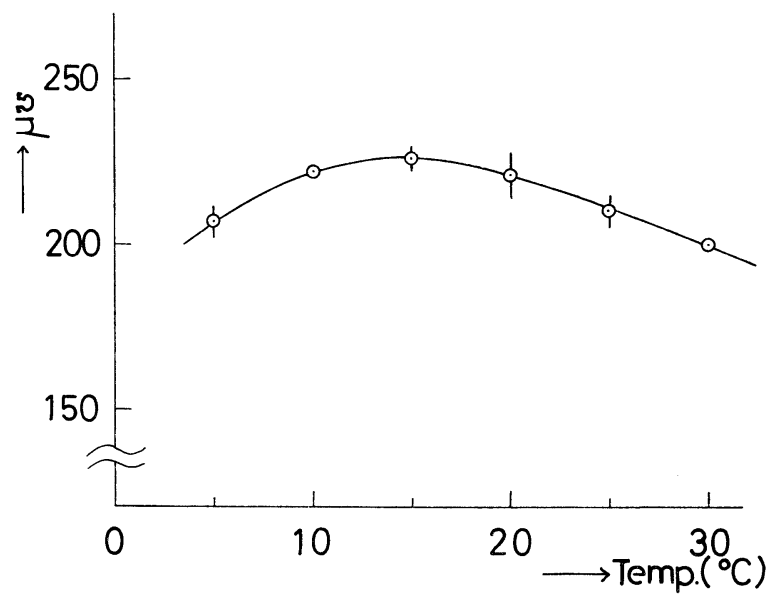

Fig. 4. Temperature dependence of the AG peak height. The electrolysis solution : $4 \times 10^{-3} M \mathrm{ZnSO}_{4}$ in $1 M \mathrm{KSCN}$. Experimental conditions are the same as in Fig. 2. Vertical line shows 95\% confidence limits. 


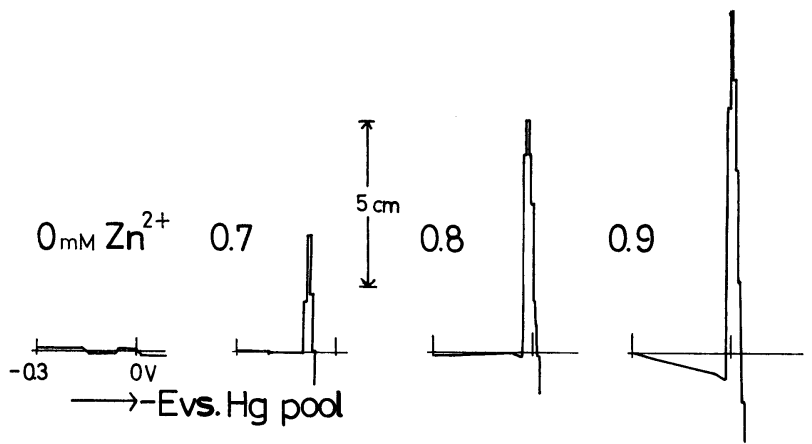

Fig. 5. High-frequency polarogram of $1 M \mathrm{KSCN}$ containing various amount of zinc ion.

Oxygen purged. $20 \pm 0.5^{\circ} \mathrm{C}$. Recorder sens. $=0.100 \mu \mathrm{A} \mathrm{mm}^{-1}$. Amplifier sens. $=1 / 20$. Damping $=10 \mu \mathrm{F}$. HF amplitude $=4$ volts. Synchro. $=$ $1-2$ sec. Gate $=2-7$.

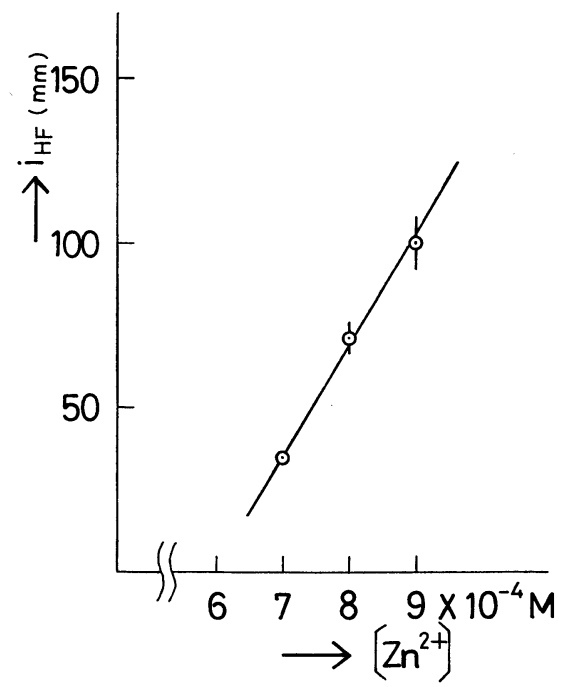

Fig. 6. Variation of the HF wave height with zinc ion concentration. Experimental conditions are the same as in Fig. 5.

As the logarithm of the overall formation constant $\beta_{4}$ for $\mathrm{Zn}(\mathrm{NCS})_{4}{ }^{2-}$ is adopted a value of 1.3 in Ringbom's monograph ${ }^{10)}$ and 3.7 in the handbook ${ }^{3)}$ by Lur'e. Freiser ${ }^{11)}$ takes a value of $\log k_{1}=1.7$ for $\mathrm{ZnNCS}^{+}$formation. If one assumes that zinc ion would exist in the environment of $1 M \mathrm{KSCN}$ as $\mathrm{Zn}(\mathrm{NCS})_{4}{ }^{2-}$, then the electrode reaction may be written as

$$
\mathrm{Zn}(\mathrm{NCS})_{4}{ }^{2-}+\mathrm{Hg}-2 \mathrm{e}=\mathrm{ZnHg}(\mathrm{SGN})_{4}
$$

When cobalt(II) ion is added in $\mathrm{m} M$ order instead of zinc ion, no change is seen in the anodic polarogram. When zinc and cobalt (II) ions are added to the $1 M$ KSCN basal solution, presumably due to the coprecipitation, a prominent AC peak appears, the height and shape of which are unstable and changes with time. As for the solubilities only a few data for tetrathiocyanatomercurate (II) are known and in the handbook $^{3)}$ by Lur'e one finds following values. 
$-\log \left[\mathrm{Zn}^{2+}\right]\left[\mathrm{Hg}(\mathrm{SCN})_{4}{ }^{2-}\right]=6.66$

$-\log \left[\mathrm{Co}^{2+}\right]\left[\mathrm{Hg}(\mathrm{SCN})_{4}{ }^{2-}\right]=5.82$

Since the cobalt salt is more soluble than zinc salt, cobalt(II) ion is supposed to be incapable of depolarizing mercury anode even in the presence of thiocyanate ion.

\section{References}

1) F. Feigl, "Spot Tests in Inorganic Analysis," translated by R. E. Oesper, 5th Ed., Elsevier, Amsterdam, 1958, p. 180.

2) G. Charlot, "L'Analyse Qualitative et les Réactions en Solution," Masson, Paris, 1957 ; Japanese Translation by K. Sone and M. Tanaka, Kyoritsu-Shuppan KK, Tokyo, 1958, p. 277, 295.

3) Yu. Yu. Lur'e, "Spravochnik po Analiticheskoi Khimii," Izdatel'stvo Khimiya, Moscow, 1965, p. 93.

4) J. Revenda, Collection Czechosl. Chem. Communs., 6, 453 (1934).

5) I. M. Kolthoff and C. S. Miller, J. Amer. Chem. Soc., 63, 1405 (1941).

6) G. J. Nyman and G. S. Alberts, Anal. Chem., 32, 207 (1960).

7) M. Ishibashi, T. Fujinaga and A. Saito, Japan Analyst, 8, 321 (1959) ; Rev. Polarog.(Japan), 7, 41 (1959).

8) B. Breyer, F. Gutmann and H. H. Bauer, Öst. Chem.-Ztg., 57, 67 (1956).

9) B. Breyer and H. H. Bauer, "Alternating Current Polarography and Tensammetry," Interscience Publishers, New York, 1963.

10) A. Ringbom, "Complexation in Analytical Chemistry," John Wiley, New York, 1963; Japanese Translation by N. Tanaka and H. Sugi, Sangyo-Tosho, Tokyo, 1965, p. 285.

11) H. Freiser and Q. Fernando, "Ionic Equilibria in Analytical Chemistry," John Wiley, New York, 1963; Japanese Translation by T. Fujinaga and E. Sekido, Kagaku-Dojin, Kyoto, 1967, p. 256.

\section{テトラチオシアナト水銀 (II) 酸亜鉛の陽極生成にもとづく 新しいポーラログラフ波}

神原 富民, 佐伯 拓治, 田中 成之

(北海道大学理学部化学教室)

$1 M \mathrm{KSCN}$ の支持電解質に $0.5 \mathrm{~m} M$ 以上の濃度 に亜鉛イオンを添加すると, テトラチオシアナト水銀 （II）酸覀鉛の三元錯体の生成による陽極波が生ずる. ての波は直流ポーラログラムでは, わずか記認め得る
程度であるが, 交流ポーラログラムでは，きわめてい ちじるしいピークを与える．電気毛管曲線と交流波高 の温度係数から，乙の新しい陽極波の復極過程には吸 着現象が関与しているととが判明した。 